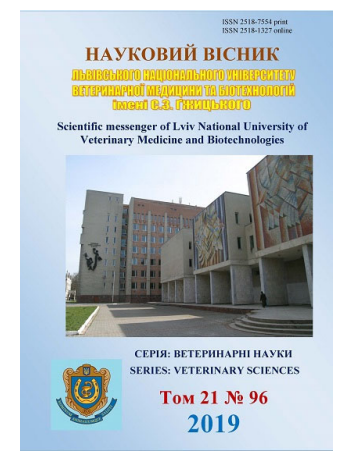

\author{
Науковий вісник Львівського національного університету \\ ветеринарної медицини та біотехнологій імені С.3. Гжицького. \\ Серія: Ветеринарні науки
}
Scientific Messenger of Lviv National University of Veterinary Medicine and Biotechnologies. Series: Veterinary sciences doi: $10.32718 /$ nvlvet9628

http://nvlvet.com.ua

UDC 664.65.05:579.22:57.06.38

\title{
Comparison of enzymatic properties of production strains of microorganisms used in the bakery industry with those of reference strains
}

\author{
O.V. Volosjanko ${ }^{1}$, M.V. Patyka ${ }^{1}$, S.A. Tereshchenko ${ }^{1}$, R.A. Pelenjo ${ }^{2}$, V.Yu. Kassich ${ }^{3}$ \\ ${ }^{1}$ National University of Life and Environmental Sciences of Ukraine, Kyiv, Ukraine \\ ${ }^{2}$ Stepan Gzhytskyi National University of Veterinary Medicine and Biotechnologies Lviv, Ukraine \\ ${ }^{3}$ Sumy National Agrarian University, Sumy, Ukraine
}

Article info

Received 04.11.2019

Received in revised form 09.12 .2019

Accepted 10.12.2019

National University of Life and Environmental Sciences of Ukraine, Heroiv Oborony Str., 15 Kyiv, 03041, Ukraine.

Stepan Gzhytskyi National University of Veterinary Medicine and Biotechnologies Lviv, Pekarska Str., 50, Lviv, 79010, Ukraine.

Tel.: +38-097-440-98-37 E-mail: andriyovich30@ukr.net

Sumy National Agrarian University, G. Kondrat'eva Str., 160, Sumy, 40000, Ukraine.
Volosjanko, O.V., Patyka, M.V., Tereshchenko, S.A., Pelenjo, R.A., \& Kassich, V.Yu. (2019). Comparison of enzymatic properties of production strains of microorganisms used in the bakery industry with those of reference strains. Scientific Messenger of Lviv National University of Veterinary Medicine and Biotechnologies. Series: Veterinary sciences, 21(96), 158-163. doi: $10.32718 /$ nvlvet 9628

The article deals with the results of the comparative analysis of the enzymatic properties of the production strains of Saccharomyces cerevisiae, Candida milleri and Lactobacillus plantarum, which were isolated from the ferment used in the production facilities of the Kiev region with the properties of the reference strains purchased in the Russian Federation. There were investigated the properties of two production strains of Saccharomyces cerevisiae and Candida milleri and one strain of Lactobacillus plantarum. The isolation of the production strains was carried out by generally accepted methods in microbiology, and their identification was carried out on the basis of the results of the investigation of morphological features and cultural and enzymatic properties according to the determinant of bacteria Burge (1997). The biochemical properties of the bacteria were studied by the indicators of their relation to oxygen, the ability to break down carbohydrates with the accumulation of certain products of metabolism. To determine the ability to ferment carbohydrates and alcohols used short and long "colored" series of Giss. The short series included environments with glucose, lactose, sucrose, maltose and mannitol, and in the long - additionally introduced environments with arabinose, xylose, rhamnose, galactose, as well as inulin, starch, dextrin and glycerol, dulcite and inositol. The incubation was carried out in a thermostat at a temperature of $30 \pm 1{ }^{\circ} \mathrm{C}$, and the results were evaluated in 2-4 days, taking into account the change whether there is no change in the color of the indicator and the environment, the appearance or absence of gas in the float, etc. Proteolytic activity was investigated for the ability of microorganisms to dilute gelatin and peptone milk, catalase - by interaction with a $10 \%$ solution of hydrogen peroxide, the ability to synthesize indole-Morel method, and ammonia and hydrogen by changing the color of the strip of litmus paper impregnated with the Andrade reagent and lead acetate solution, respectively. It is installed, that the Saccharomyces cerevisiae production strains used at the production facilities of the Kyiv region, as well as the reference strain purchased from the Russian Federation, they fermented glucose, galactose, sucrose, maltose, trehalose, melibiosis, raffinose, melecitosis and ethanol and did not ferment cellobiose, rhamnose, lactose and insulin. However, unlike the reference strains, the production strains did not have the ability to ferment xylose. Candida milleri strains, unlike Saccharomyces cerevisiae strains, do not have the ability to ferment maltose and, unlike reference strains, their production strains do not ferment xylose. The searches have found no differences in the enzymatic properties of the reference and production strain of Lactobacillus plantarum. Both microorganisms fermented glucose, galactose, sucrose, maltose, lactose, raffinose, mannitol and did not ferment rhamnose, arabinose and xylose. Based on the results of microbiological searches of production strains of Lactobacillus plantarum, Lactobacillus fermenti, Saccharomyces cerevisiae and Candida milleri, in particular the search of their enzymatic properties by means of the standardized colorimetric identification system KB009 TM HiCarburgate Kit, at the Ukrainian Laboratory of Quality and Product Safety at the AIC of the National University of Bioresources and nature management of Ukraine were certified the following strains: Lactobacillus plantarum LPR-2018/5; Lactobacillus fermenti LLF-2018/5, Saccharomyces cerevisiae SLC-2017/5, Candida milleri CLM-2017/7. 
Key words: microorganisms, bread, bakery products, enzymatic properties, carbohydrates, L. plantarum, L. fermenti, Saccharomyces cerevisiae, Candida milleri.

\title{
Порівняння ферментативних властивостей виробничих штамів мікроорганізмів, що використовуються у хлібопекарській галузі, із властивостями референтних штамів
}

\author{
О.В. Волосянко ${ }^{1}$, М.В. Патика ${ }^{1}$, С.А. Терещенко ${ }^{1}$ Р.А. Пеленьо ${ }^{2}$, В.Ю. Кассіч \\ ${ }^{1}$ Національний університет біоресурсів і природокористування Украӥни, м. Київ, Украйна \\ ${ }^{2}$ Львівський національний університет ветеринарної медицини та біотехнологій імені С.3. Гюицького, м. Львів, \\ Україна \\ ${ }^{3}$ Сумський національний аграрний університет, м. Суми, Украӥна
}

У статті наведено результати порівняльного аналізу ферментативних властивостей виробничих штамів Sассһаготусеs cerevisiae, Candida milleri i Lactobacillus plantarum, які були ізольовані із заквасок, щзо використовуються на виробничих потужностях Київької області із властивостями референтних итамів, закуплених у Російській Федерацї. Всього було досліджено властивості двох виробничих итамів Saccharomyces cerevisiae i Candida milleri та одного штаму Lactobacillus plantarum. Iзоляцію виробничих штамів проводили загально прийнятими у мікробіології методами, а їх ідентифікацію здійснювали на підставі результатів дослідження морфологічних ознаки та культуральних і ферментативнихих властивостей за визначнико бактерій Берджі (1997). Біохімічні властивості бактерій вивчали за показниками їх ставлення до кисню, здатності розщеплювати вуглеводи з накопиченням певних продуктів метаболізму. Для визначення здатності ферментувати вуглеводи і спирти використовували короткий і довгий “кольорові” ряди Гісса. Короткий ряд включав середовища з глюкозою, лактозою, сахарозою, мальтозою і манітом, а у довгий - додатково вводили середовища з арабінозою, ксилозой, рамнозою, галактозою, а також інулін, крохмаль, декстрин і глічерин, дульцит та інозит. Інкубацію проводили у термостаті за температури $30 \pm 1{ }^{\circ} \mathrm{C}$, а результати оцінювали через 2-4 доби, при цьому враховували зміну чи відсутність зміни кольору індикатора і середовища, появу або відсутність газу в поплавку тощьо. Протеолітичну активність досліджували за здатністю мікроорганізмів розріджувати желатин та пептонізували молоко, каталазну - за взаємодією із 10\% розчином пероксиду водню, здатність синтезувати індол - методом Мореля, а аміак $i$ сірководень - за зміною забарвлення смужки лакмусового папірия, просоченої відповідно реактивом Андраде і розчином аиетату свинцю. Встановлено, щу виробничі штами Sассhатотусеs сегеvіsiaе, які використовуються на виробничих потужностях Киїської області, як і референтний штам закуплений у Російській Федерачї ферментували глюкозу, галактозу, сахарозу, мальтозу, трегалозу, мелібіозу, рафінозу, мелецитозу та етанол і не ферментували целлобіозу, рамнозу, лактозу і інсулін. Проте, на відміну від референтного, виробничі итами не володіли здатністю ферментувати ксилозу. Штами Сапдіda тіlleri, на відміну від итамамів Saccharomyces cerevisiae, не володіють здатністю ферментувати мальтозу i, на відміну від референтних итамів, їх виробничі штами не ферментують ксилозу. Проведеними дослідженнями не встановлено відмінностей у ферментативних властивостях референтного та виробничого итаму Lactobacillus plantarum. Обидва мікроорганізми ферментували глюкозу, галактозу, сахарозу, мальтозу, лактозу, рафінозу, маніт і не ферментували рамнозу, арабінозу і ксилозу. На підставі результатів мікробіологічних досліджень виробничих итамів Lactobacillus plantarum, Lactobacillus fermenti, Saccharomyces cerevisiae $i$ Candida milleri, зокрема дослідження їх ферментативних властивостей проведених за допомогою стандартизованої колориметричної системи

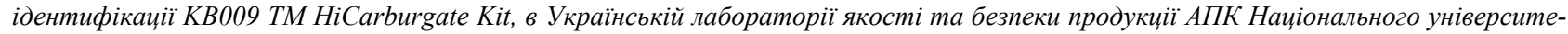
my біоресурсів та природокористування України були паспортизовані наступні итами: Lactobacillus plantarum LPR-2018/5; Lactobacillus fermenti LLF-2018/5, Saccharomyces cerevisiae SLC-2017/5, Candida milleri CLM-2017/7.

Ключові слова: мікроорганізми, хліб, хлібо-булочні вироби, ферментативні властивості, вуглеводні, L. plantarum, L. fermenti, Saccharomyces cerevisiae i Candida milleri.

\section{Вступ}

Важливе значення у соціальному захисті населення країни і однією з провідних галузей харчової промисловості України є хлібопекарська. Її виробничу базу складають близько 50 заводів 3 виробництва хліба і понад 500 міні-пекарень, які сукупно за рік виробляють 1122,6 тис. т продукції на загальну суму 14,9 млрд грн (Makarenko, 2007; Derzhavna sluzhba statystyky Ukrainy).

Однією з особливостей цієї галузі є необхідність використовувати для приготування заквасок дріжджі та мікроорганізми, від яких, безпосередньо, залежить безпечність та якість хлібобулочної продукції. Одержати ефективні виробничі закваски є можливим за умови, коли кожний виробник буде мати свій “банк” референтних штамів мікроорганізмів, які необхідно зберігати у активному стані та не допускати їх конта- кту з іншими бактеріями (Eleckij, 1978; Drobot \& Teslia, 2009).

Нині на ринку хлібо-булочних виробів різко зростає частка непромислової продукції міні-пекарень, мереж ритейлу, швидкої випічки (Zavertanyi, 2015). Необхідність регулярних закупок штамів мікроорганізмів, через відсутність національної колекцій, створює залежність таких підприємств від інших країн, зокрема Російської Федерації, підвищує собівартості продукції, а відтак і кінцеву ціну товару (Polishchuk \& Yashchyshena, 2016; Lishhynska, 2016).

Суттєвою проблемою для виробників, зокрема імпортерів хлібо-булочної виробів, є розбіжності діючих вітчизняних норм і правил із міжнародними. Це ставить українських виробників у менш вигідні умови, порівняно із виробниками країнах, в які відбувається експорт, а також з імпортерами даного виду продукції (Fedorova, 2014). 
Саме тому, проведення наукових досліджень спрямованих на вивчення біологічних властивостей існуючих референтних штамів, які використовуоться у хлібопекарській галузі, 3 метою відкриття нових більш ефективних мікрорганізмів $\epsilon$ актуальними, а їх паспортизація за морфологічними, біохімічними та генетичними показниками дасть змогу створити національну колекцію штамів й забезпечить виконання вимог Свропейського союзу, які передбачають використання офіційно зареєстрованих штамів.

Мета і завдання дослідження. Метою роботи було провести порівняльну оцінку біохімічних властивостей референтних штамів і виробничих мікроорганізмів, які використовуються у хлібопекарській галузі та паспортизацію останніх.

Для досягнення поставленої мети необхідно було вирішити наступні завдання:

- $\quad$ провести відбір проб заквасок на виробничих потужностях, виділити та ідентифікувати 3 них Saccharomyces cerevisiae, Candida milleri i Lactobacillus plantarum,

- дослідити ферментативні властивості ізольованих та референтних штамів мікроорганізмів стандартними мікробіологічними методами та за допомогою тест-системи КВ009 ТМ HiCarburgate Kit;

- провести порівняльну оцінку біохімічних властивостей референтних штамів та мікроорганізмів, які використовуються на виробничих потужностях та їх паспортизацію.

\section{Матеріал і методи досліджень}

Відбір проб заквасок для здійснювали на виробничих потужностях Київської області. Мікробіологічні дослідження проведені в Українській лабораторії якості та безпечності продукції АПК Національного університету біоресурсів і природокористування України. Всього було досліджено по 3 штами (1 референтний і 2 виробничі) Saccharomyces cerevisiae i Candida milleri та 2 штами (1 референтний i 1 виробничий) Lactobacillus plantarum.

Ізоляцію виробничих штамів проводили загально прийнятими у мікробіології методами, а їх ідентифікацію - згідно визначника бактерій Берджі (1997) на підставі результатів дослідження морфологічних ознаки та культуральних і ферментативнихі властивоcтi (Holt et al., 1997). Досліджуючи культуральні властивості звертали увагу на особливості росту мікроорганізмів у рідких і на щільних поживних середовищах. При оцінці профілю колоній, який досліджували за допомогою лупи або мікроскопа зі збільшенням $\times 8$, відмічали форму, колір, розміщення відносно середовища, контур країв, оптичні властивості, структуру тощо. Культуральні властивості характеризували за інтенсивністю росту, особливістю штриха, оптичними властивостями поверхні, кольором і консистенцією. 3 метою дослідження характеру росту бактерій в рідких середовищах посіви культур робили в м'ясопептонний бульйон. Для опису культуральних влас- тивостей використовували 4-7-добові культури, вирощені в стаціонарних умовах.

Біохімічні властивості бактерій вивчали за показниками їх ставлення до кисню, здатності розщеплювати вуглеводи 3 накопиченням певних продуктів метаболізму. Здатність мікроорганізмів ферментувати вуглеводи і спирти визначали шляхом посіву 0,10,2 см$^{3}$ суспензії досліджуваних культур в пробірки 3 рідким або напіврідким середовищем, що містило вуглевод і індикатор (“кольоровий” ряд Гісса). Короткий ряд включав середовища 3 глюкозою, лактозою, сахарозою, мальтозою і манітом, а у довгий - додатково вводили середовища 3 арабінозою, ксилозой, рамнозою, галактозою, а також полісахариди (інулін, крохмаль, декстрин) і спирти (гліцерин, дульцит, інозит). Засіяні пробірки витримували в термостаті за температурі $30 \pm 1{ }^{\circ} \mathrm{C}$. Оцінку результатів, яку робили через 2-4 доби, проводили із врахуванням зміни чи відсутності зміни кольору індикатора і середовища, появою або відсутністю газу в поплавку. На підставі отриманих даних робили відповідні висновки.

Протеолітичну активність досліджували за здатністю мікроорганізмів розріджувати желатин та пептонізували молоко, каталазну - за взаємодією із 10\% розчином пероксиду водню, здатність синтезувати індол - методом Мореля, а аміак і сірководень - за зміною забарвлення смужки лакмусового папірця, просоченої відповідно реактивом Андраде і розчином ацетату свинцю.

\section{Результати та їх обговорення}

У табл. 1 представлено результати дослідження ферментативних властивостей двох виробничих вітчизняних і референтного, закупленого у Російській Федерації, штамів Saccharomyces cerevisiae.

\section{Таблиця 1}

Ферментативні властивості штамів Saccharomyces cerevisiae

\begin{tabular}{|c|c|c|c|c|}
\hline \multirow{3}{*}{$\begin{array}{l}\text { № } \\
\text { 3/П }\end{array}$} & \multirow{3}{*}{ Органічна сполука } & \multicolumn{3}{|c|}{ Штами } \\
\hline & & \multicolumn{2}{|c|}{ Виробничі } & \multirow{2}{*}{ Референтний } \\
\hline & & № 1 & № 2 & \\
\hline 1. & Глюкоза & + & + & + \\
\hline 2. & Галактоза & + & + & + \\
\hline 3. & Сахароза & + & + & + \\
\hline 4. & Мальтоза & + & + & + \\
\hline 5. & Целлобіоза & - & - & - \\
\hline 6. & Трегалоза & + & + & + \\
\hline 7. & Рамноза & - & - & - \\
\hline 8. & Лактоза & - & - & - \\
\hline 9. & Мелібіоза & + & + & + \\
\hline 10. & Рафіноза & + & + & + \\
\hline 11. & Мелецитоза & + & + & + \\
\hline 12. & Ксилоза & - & - & + \\
\hline 13. & Етанол & + & + & + \\
\hline 14. & Інулін & - & - & - \\
\hline
\end{tabular}

Примітка: “+”- ферментує, “-”- не ферментує 
Встановлено, що виробничі штами Saccharomyces cerevisiae, які використовуються на виробничих потужностях Київської області, як і референтний штам закуплений у Російській Федерації ферментували глюкозу, галактозу, сахарозу, мальтозу, трегалозу, мелібіозу, рафінозу, мелецитозу та етанол і не ферментували целлобіозу, рамнозу, лактозу i інсулін. Проте, на відміну від референтного, виробничі штами не володіли здатністю ферментувати ксилозу.

Результати дослідженнями ферментативних властивостей виробничих і референтного штаму Candida milleri представлено у табл. 2.

Таблиця 2

Ферментативні властивості штамів Candida milleri

\begin{tabular}{|c|c|c|c|c|}
\hline \multirow{3}{*}{$\begin{array}{l}\text { № } \\
3 / \Pi\end{array}$} & \multirow{3}{*}{ Органічна сполука } & \multicolumn{3}{|c|}{ Штами } \\
\hline & & \multicolumn{2}{|c|}{ Виробничі } & \multirow{2}{*}{ Референтний } \\
\hline & & № 1 & № 2 & \\
\hline 1. & Глюкоза & + & + & + \\
\hline 2. & Галактоза & + & + & + \\
\hline 3. & Сахароза & + & + & + \\
\hline 4. & Мальтоза & - & - & - \\
\hline 5. & Целлобіоза & - & - & - \\
\hline 6. & Трегалоза & + & + & + \\
\hline 7. & Рамноза & - & - & - \\
\hline 8. & Лактоза & - & - & - \\
\hline 9. & Мелібіоза & + & + & + \\
\hline 10. & Рафіноза & + & + & + \\
\hline 11. & Мелецитоза & + & + & + \\
\hline 12. & Ксилоза & - & - & + \\
\hline 13. & Етанол & + & + & + \\
\hline 14. & Інулін & - & - & - \\
\hline
\end{tabular}

Примітка: “+”- ферментує, “-”- - не ферментує

Аналізуючи одержані дані видно, що штами Candida milleri на відміну від штамамів Saccharomyces cerevisiae, не володіють здатністю ферментувати мальтозу i, на відміну від референтних штамів, штами Candida milleri ізольовані із заквасок, відібраних на виробництві, не ферментують ксилозу.

У різних галузях харчової промисловості, у тому числі і хлібопекарській, широко використовують Lactobacillus spp. Лактобацили, як один 3 основних компонентів пристінної мікрофлори кишечнику, здатні в організмі людини ініціювати метаболізм вуглеводів, білків, ліпідів, нуклеїнових кислот, водносольовий обмін, підтримувати $\mathrm{pH}$ і регулювати анаеробіозу у кишечнику, забезпечувати енергією епітеліальні клітини шлунково-кишкового тракту, сприяти рециркуляції жовчних кислот, стероїдів, продукувати біологічно активні сполуки, впивати на імуногенну дію та брати участь у формуванні імунологічної толе- рантності до харчових і мікробних антигенів, забезпечують колонізаційную резистентність тощо..

Однак, саме бактерії роду Lactobacillus, внаслідок своєї кислотостійкості і здатності продукувати велику кількість молочної кислоти, досить часто $є$ причиною псування харчових продуктів, як на етапі виробництва, так і зберігання (Solov'eva et al., 2014).

У табл. 3 наведено дані ферментативних властивостей Lactobacillus plantarum. Аналізуючи одержані дані нами не встановлено відмінностей у ферментативних властивостях референтного та виробничого штаму Lactobacillus plantarum. Обидва мікроорганізми ферментували глюкозу, галактозу, сахарозу, мальтозу, лактозу, рафінозу, маніт і не ферментували рамнозу, арабінозу і ксилозу.

\section{Таблиця 3}

Ферментативні властивості штамів Lactobacillus plantarum

\begin{tabular}{clcc}
\hline \multirow{2}{*}{ o } & \multirow{2}{*}{ Органічна сполука } & \multicolumn{2}{c}{ Lactobacillus plantarum } \\
\cline { 3 - 4 } з/п & \multicolumn{1}{c}{ виробниий } & референтний \\
\hline 1. & Глюкоза & + & + \\
2. & Галактоза & + & + \\
3. & Сахароза & + & + \\
4. & Мальтоза & + & + \\
5. & Рамноза & - & - \\
6. & Лактоза & + & + \\
7. & Арабіноза & - & - \\
8. & Рафіноза & + & + \\
9. & Манніт & + & + \\
10. & Ксилоза & - & - \\
\hline Примітка: ““”- ферментує, “-”- - не ферментує
\end{tabular}

3 метою паспортизації штамів Lactobacillus plantarum, Lactobacillus fermenti, Saccharomyces cerevisiae i Candida milleri, за допомогою стандартизованої колориметричної системи ідентифікації КВ009 ТМ HiCarburgate Kit було досліджено (табл. 4) їх здатність ферментувати 35 вуглеводнів.

На підставі результатів мікробіологічних досліджень, зокрема ферментативних властивостей визначених за допомогою стандартизованої колориметричної системи ідентифікації КВ009 ТМ HiCarburgate Kit, в Українській лабораторії якості та безпеки продукції АПК Національного університету біоресурсів та природокористування України були паспортизовані наступні штами: Lactobacillus plantarum LPR - 2018/5; Lactobacillus fermenti LLF2018/5, Saccharomyces cerevisiae SLC-2017/5, Candida milleri CLM-2017/7. 


\section{Таблиця 4}

Результати досліджень ферментації вуглеводнів штамами мікроорганізмів за допомогою тест-системи КВ009 TM HiCarburgate Kit

\begin{tabular}{|c|c|c|c|c|c|}
\hline \multirow{2}{*}{ № } & \multirow{2}{*}{ Carbohydrates } & Lactobacillus plantarum & Saccharomyces cerevisiae & Lactobacillus fermenti & Candida miller \\
\hline & & LPR & SLC & LLF & CLM \\
\hline 1. & Lactose & + & - & +- & - \\
\hline 2. & Xylose & - & - & - & - \\
\hline 3. & Maltose & + & + & + & - \\
\hline 4. & Fructose & + & - & - & - \\
\hline 5. & Dextrose & + & + & - & - \\
\hline 6. & Galactose & + & + & + & + \\
\hline 7. & Raffinose & + & + & +- & + \\
\hline 8. & Trehalose & + & + & - & + \\
\hline 9. & Melibiose & - & + & - & - \\
\hline 10. & Sucrose & + & + & +- & +- \\
\hline 11. & L-Arabinose, & - & - & - & - \\
\hline 12. & Mannose & + & - & - & - \\
\hline 13. & Inulin & + & - & - & - \\
\hline 14. & Sodium gluconate & - & - & - & - \\
\hline 15. & $\alpha$-Methyl-D-glucoside & - & - & - & - \\
\hline 16. & Glycerol & - & - & - & + \\
\hline 17. & Salicin & - & - & - & - \\
\hline 18. & Dulcitol & - & - & - & - \\
\hline 19. & Inositol & - & - & - & - \\
\hline 20. & Sorbitol & - & - & - & - \\
\hline 21. & Mannitol & - & - & - & - \\
\hline 22. & Adonitol & - & - & - & - \\
\hline 23. & Arabitol & - & - & - & - \\
\hline 24. & Erythritol & - & - & - & - \\
\hline 25. & Rhamnose & - & - & +- & - \\
\hline 26. & Cellobiose & - & - & - & - \\
\hline 27. & Melezitose & + & - & - & - \\
\hline 28. & $\alpha$-Methyl-D-Mannoside & - & - & - & - \\
\hline 29. & Xylitol & - & - & +- & - \\
\hline 30. & ONPG & - & - & - & - \\
\hline 31. & Esculin & + & - & - & - \\
\hline 32. & D-Arabinose & - & - & +- & - \\
\hline 33. & Citrate & - & - & - & - \\
\hline 34. & Malonate & - & - & - & - \\
\hline 35. & Sorbose & - & - & - & - \\
\hline 36. & Control & - & - & - & - \\
\hline
\end{tabular}

\section{Висновки}

1. Дослідженнями ферментативних властивостей мікроорганізмів, які використовуються на виробничих потужностях Київської області встановлено, що ізоляти Saccharomyces cerevisiae i Candida milleri, на відміну від референтних штамів, не ферментують мальтозу, а Lactobacillus plantarum - зовсім не відрізнявся від референтного штаму за ферментативними властивостями.

2. На підставі проведених досліджень паспортизовано штам Lactobacillus plantarum LPR-2018/5, штам Lactobacillus fermenti LLF-2018/5, штам Saccharomyces cerevisiae SLC-2017/5 і штам Candida milleri CLM-2017/7.
Перспективи подальших досліджень. В подальшому планується провести дослідження біологічних властивостей мікроорганізмів і дріжджів, які використовуються на виробничих потужностях хлібопекарської галузі у інших регіонах України, їх паспортизацію для створення власних референтних штамів та гармонізації діючих вітчизняних норм і правил із міжнародними.

\section{References}

Derzhavna sluzhba statystyky Ukrainy: Ofitsiinyi sait [Elektronnyi resurs]. Rezhym dostupu: http://www.ukrstat.gov.ua (in Ukrainian).

Drobot, V.I., \& Teslia, O.D. (2009). Yakist vitchyznianykh khlibopekarskykh drizhdzhiv. Naukovi pratsi 
Odeskoi natsionalnoi akademii kharchovykh tekhnolohii, 36(1), 111-114. http://nbuv.gov.ua/ UJRN/Np_2009_36\%281\%29_33 (in Ukrainian).

Eleckij, I.K. (1978). Vlijanie skorosti gazoobrazovanija drozhzhej na rasstojku zagotovok i kachestvo hleba. HKP, 11, 15-17 (in Russian).

Fedorova, T.V. (2014). Stratehichne upravlinnia konkurentospromozhnistiu khlibopekarskykh pidpryiemstv. Khersonskyi derzhavnyi ahrarnyi universytet "Molodyi vchenyi”, 8(11), 53-56. http://nbuv.gov.ua/ UJRN/molv_2014_8(2)_14 (in Ukrainian).

Holt, Dzh., Krig, N., \& Snit, P. (1997). Opredelitel' bakterij Berdzhi v 2-h t. T.1. Moskva: Mir (in Russian).

Holt, Dzh., Krig, N., \& Snit, P. (1997). Opredelitel' bakterij Berdzhi v 2-h t. T. 2. Moskva: Mir (in Russian).

Lishhynska, V.V. (2016). Konkurentne seredovyshhe pidpryyemstv xlibopekarskoyi promyslovosti Ukrayiny. Strategichni imperatyvy suchasnogo menedzhmentu: zb. materialiv III Mizhnar. nauk.prakt. konf. Kyiv: KNEU, 49-55 (in Ukrainian).

Makarenko, V. (2007). Vsia pravda pro khlib. Ahro Perspektyva, 6(7), 24-27 (in Ukrainian).
Polishchuk, I.I., \& Yashchyshena, Ya.O. (2016). Problemy ta perspektyvy rozvytku khlibopekarskoi haluzi v Ukraini. Molodyi vchenyi, 5(32), 131-133. http://molodyvcheny.in.ua/files/journal/2016/5/34.pdf (in Ukrainian).

Solov'eva, I.V., Tomilina, A.G., Belova, I.V., Novikova, N.A., \& Ivanova, T.P. (2014). Biologicheskie svojstva laktobacill. perspektivy ispol"zovanija v laboratorijah rospotrebnadzora jekspress-metodov amplifikacii nukleinovyh kislot (MANK) pri kontrole kachestva pishhevyh produktov, bad $\mathrm{k}$ pishhe, lekarstvennyh form, soderzhashhih laktobacilly. Magazine Medial, Analytical Reviews, 2(12), 29-44. https://cyberleninka.ru/article/n/biologicheskiesvoystva-laktobatsill-perspektivy-ispolzovaniya-vlaboratoriyah-rospotrebnadzora-ekspress-metodovamplifikatsii/viewer (in Russian).

Zavertanyi, D.V. (2015). Suchasnyi stan ta perspektyvy rozvytku khlibopekarskoi haluzi Ukrainy. Rynkova ekonomika: suchasna teoriia i praktyka upravlinnia, 14(2), 194-203. doi: 10.18524/24139998.2015.2.61705 (in Ukrainian). 